\title{
Confucian Leadership and Corporate Social Responsibility (CSR), the Way Forward
}

\author{
Low Kim Cheng Patrick \\ Universiti Brunei Darussalam \\ Ang Sik Liong \\ Universiti Brunei Darussalam
}

\begin{abstract}
In the face of accelerating tumult and change, leaders and policy makers need or should seek new ways of thinking and actions to sustain business performance and growth in line with Corporate Social Responsibility (CSR). Asian countries including China, South Korea, Taiwan, Vietnam, Japan and Singapore are fast emerging or becoming dominant global business players; the recent rapid heating and rise of the Chinese economy has an impact on the overall global economy as well as the balance of power in the world. It is interesting to note that all the said Asian countries have been influenced historically in one way or another by the Confucianism and its form and style of leadership. In this paper, the authors interpret and present Confucian leadership and business lessons derived from the wisdom of Confucius. From Confucian leadership come the emphasis on positive business dealings and harmonious relationships as well as the value of learning and education; and these bring many benefits and good practices including good business management and corporate social responsibility. The understandings and practices of Confucian leadership in a business organization coupled with the awareness, theory and applications of the corporate social responsibility can indeed bring much peace, learning and economic growth for both the organizational and communal well-being in the region.
\end{abstract}

Keywords: Confucian leadership, Corporate Social Responsibility (CSR), Confucian values.

\section{Introduction}

Keith Rupert Murdoch, an Australian-American media mogul and the Chairman, and CEO of News Corporation once said in the early 90s, "The world is changing very fast. Big will not beat small anymore. It will be the fast beating the slow" (BBL, 2011). Very truly, business leaders and managers, nowadays, are facing accelerating 
turbulence and change and they need or should seek fresh ways of thinking and actions to sustain their business performance and growth in a global setting. Recently, Murdoch himself has faced the shutdown of his 168 years old newspaper due to phone hacking scandals (CNN News, 2011). On the other hand, we are also living in a world with too many problems such as, to name a few, different kinds of pollutions, violence, financial institutions collapse, environmental problems, global warming and a host of others - yet there are too few answers (Low, 2009; 2009a). Because of these happenings, business leaders face great challenges in bringing back their business to normal and most of them have to pay penalty or face bankruptcy. Take, for example, the recent earthquake and tsunami in Japan had resulted in nuclear leak and environmental pollution from the ailing Fukushima plant and this is considered to be the world's worst nuclear crisis since Chernobyl, and Chernobyl, as we all know it, was bad. Tokyo Electric Power Company (Tepco) apologized to the country at large and announced that it would pay compensation to the affected residents. In the parliament, Japanese lawmakers questioned and grilled the president of the company on nuclear safety measures; they wanted him to take responsibility for the disaster (Singapore Straits Times, 2011). Therefore, it is very important for an individual whether (s)he is a business leader, a manager or an employee in an organization to be cautious and aware, more so, to embrace the business code ethics and be socially responsible.

One has to do so or should feel compelled because firstly, the public at large expects corporate leaders/managers to apply ethical principles in their businesses. Secondly, most people expect business to be more socially responsible day by day. Thirdly, people especially the green peace activists put forth that human beings share a single planet with finite natural resources, and it is crucial to ensure the sustainability of the supplies and the resources for present and future generations. Lastly, new sciences and technologies bring along new ethical situations and concerns such as genetically modified, high yielding crops/food or nuclear crises that might cause safety and health problems, yet there are also other threats including scams, online frauds, invasion of privacy, internet pornography. Indeed, many tough situations and ethical concerns exist. Moreover, on the contrary, there is much competitive pressure to succeed, businesses must succeed. People may make their own luck by any means; worse, at times, the means may justify the ends. They would say: "attack or be attacked" so much so that even the movie "Greed is good" [as proclaimed by the Michael Douglas character, Gordon Gekko, in the 1987 Hollywood movie, Wall Street] seems to be fast becoming a reality (Low, 2008).

However, one must realize that each of us has a social responsibility. Looking at the bigger picture, one must also agree that each firm has a social responsibility which is the firm's recognition of how its business decisions can affect society. Ethics, the yardstick, serves as the foundational stone of doing business and it should play a critical role in every business, profit or non-profit organization, society, and nation. Ethics pays. Being ethical imparts a sense of trust which promotes positive alliances among business partners and associates. Confucian leadership can provide the basis through which people do, conduct business or make business decisions. In this paper, the objectives are of two folds: Firstly, is to define CSR in the Confucian-influenced Asian countries, and secondly, is to examine the benefits and relevance of Confucian 
teachings in line with CSR both for economic growth and community well-being of the region.

\section{Who Is Confucius?}

Confucius (551 BC - 479 BC) was an esteemed Chinese thinker and social philosopher. The philosophy of Confucius emphasized personal and governmental morality, correctness of social relationship, justice, and sincerity. Just over two thousand years ago, the great Han Dynasty Emperor Wu (156 BC - 87 BC), rejected a hundred other philosophical schools in favor of Confucius, effectively making China a Confucian (leadership) state (Yu, 2008). Until the mid-twentieth century, China was so inseparable from the idea of Confucius that her scheme of government and society, her concept of self and relationships, her construct of culture and history all seem to have originated from his mind alone (Chin, 2008). His teachings and philosophy have deeply influenced or etched Chinese, Japanese, Korean and Vietnamese thought, life, leadership and organisational culture (Chin, 2008; Chew, 2000) and also elsewhere, even in the Western world (Yang, 1993). His ideas have, in fact, been lasting.

\section{Coporate Social Responsibility (Csr)}

Coporate Social Responsibility is defined by the WBCSD (World Business Council for Sustainable Development) as "Corporate social responsibility is the continuing commitment by business to behave ethically and contribute to economic development while improving the quality of life of the workforce and their families as well as of the local community and society at large." (WBCSD, 2000). In 2002, the definition was further simplified to, "Corporate social responsibility is the commitment of business to contribute to sustainable economic development, working with employees, their families, the local community and society at large to improve their quality of life." (WBCSD, 2002).

It is worthy to note what Warren Buffet said about business, "It takes twenty years to build a reputation and five minutes to ruin it." The reason being that nowadays, consumers, investors, governments and even employees has become more sophisticated and more aware of good corporate behavior, or lack thereof. In this new business environment, a company's reputation has become one of its most valuable assets, and CSR has become one of the key components of corporate reputation. Positive CSR experiences build confidence and goodwill with stakeholders.

Corporate Social Responsibility (CSR, also called corporate conscience, corporate citizenship, social performance, or sustainable responsible business) is a form of corporate self-regulation integrated into a business model. CSR policy functions as a built-in, self-regulating mechanism whereby business monitors and ensures its active compliance with the spirit of the law, ethical standards, and international norms. The goal of CSR is to embrace responsibility for the company's actions and encourage a positive impact through its activities on the environment, consumers, employees, communities, stakeholders and all other members of the public sphere. 


\section{Leadership and the Organisational Culture}

Leadership can be defined as the process of influencing others to facilitate the attainment of organisational relevant goals and this definition is applicable to both formal and informal leadership position in order to exert leadership behaviour. (Ivancevich et al.,2008). Literature articles written on leadership styles have shown that effective leaders must be pro-active; must be able to accept change; leading and managing change (Low, 2010; 2010a \& 2010b).

Leadership is the driving force of organizations and it has played an important role in every profit or nonprofit organization, society, and nation. Leaders' capability and behavior may embody strong ethical values in organizational culture; they change organizational structures by exercising their influence over organizations; they create organizational culture; and they take the initiative for the alteration of organizations. In practice, leadership is not only a core factor for the execution of administration for management, but also a significant part for the creation of new organizational culture. In other words, leadership is regarded as an essential element or a core value in organizational culture. In this vein, leadership and organizational culture are inseparable.

\section{Confucian Leadership}

Confucius said that a leader should be upright and act with integrity in order to lead his people effectively and he said this in a very positive manner, "If the leader acts properly, the common people will obey him without being ordered to; if the leader does not act properly, the common people will not obey him even after repeated injunctions." (Analects of Confucius XIII: 6). Stressing on the importance of an upright leader, he further remarked confidently, "Why should a leader have any difficulty in managing and administrating his country if he is upright? How could a leader correct others if he himself is not upright?" (Analects of Confucius XIII: 13). So, what does he mean by an upright leader? Considering the Confucian sociopolitical norms for the leader, Confucius suggests that those who want to be leaders have to be ethical in having virtuous characters and attitudes. For personal cultivation, Confucius encouraged and asserted on a harmonious interpersonal relations in social organizations, that is, reciprocally obligatory relationship on the ground of hierarchical relations.

Furthermore, Confucius remarked, "The jūnzì (gentleman) understands what is right; the petty man understands what will sell." (Analects of Confucius IV: 16). In another words, the gentleman has the proper virtue and understanding of doing things right. He understands what is right and what is wrong when doing business. The petty man, on the other hand, only understands what can make him rich. In Confucius' mind, leaders had an obligation to cultivate themselves morally; to demonstrate filial piety and loyalty; and to act with benevolence towards their fellow men. Therefore, Confucian leadership emphasized correct moral and ethical behaviour of both the individual and the government. It underscored the importance of social relationships, 
justice and sincerity. In short; it was aimed at creating peace and harmony in a society with social responsibility.

Henceforth, the aim and purpose of Confucian leadership is to lead and encourage people to carry out a proper life and livelihood and have good relationships with the people around oneself so that more people would attain similar good virtues; and if this continues to be so, there would be fewer frictions in relationships and thus this creates positive energies in group dynamics and teams. All would then be working towards a peaceful and harmonious society, and since everybody behaves in a socially responsible way, the people in business, when relating with their stakeholders (community and society) would be able to prosper in doing their businesses. Furthermore, there would be fewer problems in business dealings and transactions in the wider society and country.

\section{Confucian Values}

To practice Confucian leadership one should uphold the following Confucian values:

\section{The Value of Gentleman(lady) (Junzi)}

George Bernard Shaw has said, "A gentleman is one who puts more into the world than he takes out." This is very true, even for the fifth century Chinese sage Confucius, a person more so, a leader should uphold the value of Junzi (acting and behaving as gentleman(lady). If we were to achieve a state of orderliness and peace, we need to return to the traditional concept of virtue. Virtue is a good quality and way of behaving and is based entirely on the value of Junzi. Confucius believed that human nature is basically good. However, he also believed that this goodness needs to be nurtured and cultivated and the best way to do so is through education.

According to Confucius, "unending strength, resoluteness, simplicity and reticence are close to benevolence" which is attainable through self-cultivation, education and performance of the $l i$ or rituals/code of behaviour (Story, 2007 cited in Low, 2010c). This also meant that for one to live like a gentleman (lady), one must have the positive qualities of achieving goals and being resilient; not to change one's mind and give up a course of action easily; simplify things rather than make things complicated and being always proactive before saying out things that have not yet been accomplished. Interestingly, in a capsule, just as Confucius has said, "It is man that makes truth great, and not truth that makes man great." and "the measure of man is man" (Lin, 1994: 183). Therefore, a so-called great man/lady has to be consistently carrying out good things in a truthful manner to him/her and to others all the times; and even without other people noticing, (s)he should do good and not that (s)he has done just a few visible and truthful things in the past to be recognized as a great $\mathrm{man} / \mathrm{lady}$.

In Confucius' teachings, 'ren' means benevolence/humanity (love to all men, de Bary, Chan and Watson 1960 cited in Low, 2006) and Confucian leader must practise 'ren'. Being benevolent is synonymous with being a gentleman. Obviously, being a gentleman, the Confucian leader must take care of the interests and needs of all his followers and supporters. 
In short, humanism and true manhood is stressed. "A gentleman understands what is moral, a base man understands what is advantageous or profitable" (Chew, 2000: 9). Confucian leader needs to live up to his/her character and integrity in order for his/her followers to respect him/her. Needless to say, if a gentleman were to go and live among uncivilized peoples, then how could these peoples be crude? His very gentlemanly character and actions will influence and help to change them for the better.

Zǐ Gòng, a disciple, once asked Confucius, "Is there a single word that a man can follow and practice as his principle of good conduct for life?" Confucius replied, "It is, perhaps, the word, shì or reciprocity. That is 'not to do unto others what one does not want others to do unto oneself' (Analects of Confucius, XV: 24; Lin, 1994: 186). The authors are inclined to favour the Confucian's overall anchor, the Golden Rule, that is, in a positive way, as a gentleman, "One should treat others as one would like others to treat oneself." Applying this principle into the corporate social responsibility, this means that one moves away from oneself and becomes less selfcentred, more thinking of others, and in fact, more altruistic. All businesses should recognize their responsibilities to the employees and to the public at large and make decisions that reflect these responsibilities in clear and transparent ways. Here, the business can then engage the people moving from inactive to reactive to proactive and to interactive. The basic point is that one can argue that business cannot avoid communication but has to enter into dialogue, do something, and engage with the people- market or non-market - in an ongoing responsive relationship.

In business, being a jūnž̆, a leader is courageous, honest and has a real sense of commitment to transparency. One has the mental and moral strengths to venture, persevere and withstand difficulties. One would enhance CSR by leading one's corporation in a responsible way; a leader is responsible to all his or her stakeholders (Low \& Ang, 2011).

\section{The Value of Prudence}

A Latin proverb speaks of, "Believe nothing and be on your guard on everything" and interestingly, Thomas Jefferson, the American 3rd US President (1801-1809), also said in a similar theme when dealing with public expenditure, "The same prudence which in private life would forbid our paying our own money for unexplained projects, forbids it in the dispensation of the public moneys." Prudence is care and good sense when making a decision or taking action. Being prudent is also another trait of the Confucian leadership.

Ž̌ Zhāng asked Confucius, "In what way should a person in authority act in order that he may conduct government properly?" The Master replied, "Let him observe the five excellent things, and banish away the four bad things, then he may conduct government properly." And one of the five excellent things is as Confucius replied: "When the person in authority is beneficent without great expenditure" (Analects of Confucius, $X X: 2$; Pay, 2000).

In Singapore, Low's (2009b; 2002) and Low's (2005) studies support that strongly influenced by Confucianism, the Chinese mind is said to be pragmatic and devoted to 
seeking profit. Such a company culture, particularly in some Chinese small and medium companies such as in the "mee pok (noodle) seller corporate culture" (Low, 2005), what is critical is that profits are ploughed back and being frugal is a virtue. Here, thrift involves the use of limited resources - material, capital and human resources, and these results in improving productivity and overall profitability. In Asia including in Singapore, savings and accumulation of wealth through hard work and thrift have often been cited as key strategies of early Chinese settlers to establish their own small businesses (Menkhoff, 1993 cited by Low, 2010c). In fact, Low's (2005a) study supports that being prudent is one of the success values for the growth of Singapore companies. And Low (2006b) argues that being prudent also serves a crisis prevention, containment and management for the island- Republic of Singapore.

With regard to CSR, the authors feel that overproduction would lead to global wastage of natural resources including materials and energy as well as a surplus of supply over demand. One must very well realize that buyer values changes over time and a company which benchmark with other companies may not perceive or act on these values (or customer need) change. In this regard, the company should therefore conitnuously go/resort to the first principle of marketing, that is, looking at and producing products catering to customers and their needs. Producing based on customer's needs would essentially reduce wastage since only what is duly wanted is produced. When the company produces what is essential to the customers, they are subscribing to CSR for they are, in fact, conserving energy, materials and resources as well as ensuring or upholding the human dignity, for example, to cut costs, companies also rely on developing countries and at times, they may resort to subcontractors who may be dependent on child labor which should, in fact, be abolished (Low \& Ang, forthcoming).

\section{The Value of Resilience}

Resilience means facing life's difficulties with courage and patience - refusing to give up. It is the quality of character that allows a person or group of people rebound from misfortune, hardships and traumas. In this regard, Confucius said, "In making a mound, the job is not finished until the last basketful of earth is in place; in filling in a hole, even if you have only poured in one basketful of earth, the job can surely be finished so long as you are vigilant and persist in doing it" (Analects of Confucius, IX: 19). It is noted that Confucius used a metaphor to encourage his disciples to be resilient and to strive to improve themselves constantly and not to give up halfway.

There is a Buddhist saying which goes, "If we are facing in the right direction, all we have to do is keep on walking" and the meaning is very similar to what Lucretius (ca. 99 BC) who said, "The drops of rain make a hole in the stone not by violence but by soft falling." Perseverance in doing thing, in fact, is a key to success. Yeung and Tung's (1996) PRC (People's Republic of China) study (cited in Low, 2002) has found that a relationship exists between certain Confucian values (such as perseverance) and firm performance. Perseverance and industriousness lead logically to focus, working towards the company goals that enhance company profitability, adding to corporate success. Indeed, the value of resilience can be considered as the people's or followers' vitality and their drive and, indeed, the latter has made 
countries such as Germany, Japan and South Korea (Isaak, 1997) economically successful. Indeed we can also argue that the Confucian leadership style can be seen as practicing resilience too. Prudence also adds to the resilience of the leaders and Singapore's economic strengths (Low, 2008; 2006b). The Confucian leader is bold. "Act resolutely, and both heaven and hell will respect you" (Matsushita, cited in PHP, 1991: 39). As a leader, when you make up your mind to do something, you must have the determination to carry it out. Additionally, as Confucius puts it, "One who has his arms broken three times may become a good doctor" (Zhou, 2005: 170). Confucius has further pointed out that: ... a king can't become a real ruler without encountering difficulties; and soldiers can't become crack troops without suffering setbacks (Zhou, 2005: 171).

To cite a practical example, the researchers would highlight these: With the Confucian Heritage culture (Low, 2009; 2006a; 2005; 2002), Singapore's ejection from Malaysia in 1965, its caesarean national birth and the influence of other factors as highlighted by Low (2007a), Singapore/ Singaporeans are said to possess resilience. Most or older workers, who have lost their jobs, persevere in finding jobs, and being flexible being open to options in their job search. In times of recession and unemployment, they search for opportunities to keep afloat. Perhaps, this could be interpreted as Confucian leadership of the ordinary people in their everyday lives. They, in fact, subscribe very much to the Chinese saying of "not be afraid of going slow, but be very much afraid of standing still" (Low, 2008; 2007a). Interestingly, the resilient leader also learns; hence he is able to correct himself, strengthens and grows. In the Analects, Confucius presents himself as a "transmitter who invented nothing" (Wikipedia, 2007). He put the greatest emphasis on the importance of study or learning, highlighting that: Not to correct the mistake one made is to err indeed (Zhou, 2005: 79). Never be afraid of correcting mistakes one has made (Zhou, 2005: $80)$. In a company of two friends, one learns from one the good examples and from the other mistakes which can then avoid. Confucius has relevantly highlighted that one is: capable, one must study; to be intellectual, one must learn from others (Zhou, 2005: 36), profit(ing) by good examples and avoid(ing) bad examples. (Chew, 2000: 13). To this researcher, this means that the Confucian leader learns, benchmarks, learns and improves. Hence, we can also add the touch of Kaizen (continuous improvement). Continuous improvement indeed builds and grows the resilience in a leader.

A resilient leader would never give up and would continue to strive for sustainable development of one's business by implementing ethical codes of conduct in one's organisation. One would also enhance CSR by seeking or creating partnerships between one's corporation and its stakeholders to develop strategies and ways for environmental and sustainability issues such as climate change, waste, sustainable development and corporate social responsibility towards a greener environment and a better society.

\section{The Value of Personal Commitment In Taking Responsibility}

A good leader should uphold the value of personal commitment in taking responsibility. A promise is personal commitment to do or not to do something. In terms of being responsible to oneself and others, Zēng Zǐ , a disciple of Confucius, 
highlighted these, "Every day I examine myself once and again: Have I tried my utmost to help others? Have I been honest to my friends? Have I diligently reviewed the instructions from the Master?" (Analects of Confucius, I: 4) Hence forth, it is important that an individual should be responsible to what (s)he is doing and also what others are doing around him/her. When one looks at a bigger picture, it is axiomatic that a leader should be responsible to his people and environment.

Leaders who have really internalised such core values would enhance, if not ensure, their personal commitment. To be an effective leader, one should have great overall, if not, moral courage to step forward and face the challenges of decision-making in alignment with corporate social responsibility. One takes responsibility and performs tasks accordingly to one's own belief for the betterment of a peace, harmonious and sustainable society.

\section{The Value of Sincerity and Integrity}

Confucius remarked, "Man's existence lies in his integrity. A man without integrity can exist merely through his luck" (Analects of Confucius, VI: 19). A person's integrity of being truthful and sincere to oneself and society is of great importance and it appears that many often overlooked that the essence of Confucianism is the "idea of being true to oneself in this world" (interestingly, there is an intrinsic or inside-out approach) when fulfilling obligations to family and others in society (Wang, 2004: 51). When one is truthful to oneself, one would then be able to fulfil one's obligation to look after one's family in a caring and sincere way. When an individual can achieve this, then for one to care and contribute to one's society would come in a natural way. Therefore, sincerity and integrity of an individual are the key strengths of the Confucian ethics when applied to the stakeholder theory/ others in society (Low \& Ang, 2011). Whatever, even very little that each of us, individuals and business leaders can do for our respective universe that would be great. After all, it would contribute to the overall goodness, similar to what the late Indian nationalist leader Mohandas Gandhi (1869-1948) said, that is, "be the change you want to see in the world." And individuals do make a difference in ethical actions. Being a sincere and reliable business leader, one can work confidently in partnerships with the stakeholders such as the government, the political parties and the civil society to safe guard and advance the future of a society with corporate social responsibility.

\section{The Value of Stressing On and Practising Virtue}

Virtue is thinking and doing what is right and avoiding what is wrong. Virtue is something to be desired highly. But why virtue is stressed? Aristotle (384 BC - 322 BC) said, "The greatest virtues are those which are most useful to other persons." What Aristotle meant is that one should think and work for the benefit of the society as a whole in a socially responsible way (and not for benefit of an individual or for a few people only). Therefore, virtue is thinking and doing what is right and avoiding what is wrong; useful to other persons. When virtue is practised, one also enjoys a clear conscience. And a clear conscience is like a soft pillow, and one sleeps well. "A gentleman finds peace of mind in virtue and he covets it" (Confucius cited in Chew, 2000: 8). Rightly too, Confucius has highlighted that "likes and dislikes should not affect our judgment. We should be on the side of what is right and against what is 
wrong" (Chew, 2000: 9). Again, on anything we do, we should have a clear conscience on what is right and what is wrong.

In this aspect, one's good example is critical. Without example, a leader becomes "a person who lacks gravity (and) does not inspire respect" (Confucius cited in Chew, 2000: 2, italics ours). A leader gains moral grounds and attracts his followers through his examples. His actions are louder than words.

As highlighted by Low (2006), role models should be assessed in the light of honesty and integrity. When comes with the time that the followers have doubt and question their leaders' honesty and integrity, leaders cannot be role models. For small and medium Chinese business leaders, it is a matter of face or honour. In the case of Singapore's national values, Low $(2011 ; 2009 b ; 2002)$ speaks of the Confucian Heritage, here, it should be noted that in 2010, Singapore, together with Denmark and New Zealand, were ranked as the first most corruption free among 178 countries because all three countries scored the same CPI of 9.3. The CPI (Corruption Perception Index) scores countries on a scale of zero to 10, with zero indicating high levels of corruption and 10, low levels. (Transparency International, 2010). Singapore with a score of 2.194 was ranked among the top ten nations in the world in government effectiveness in the 2010 World Bank's "Worldwide Governance Indicator 2010" Report (World Bank Institute, 2010). It is noted that the governance indicators are measured in units ranging from about -2.5 to 2.5 , with higher values corresponding to better governance outcomes. The Singapore's People Action Party (PAP) track record and ability to fight off critics based on honesty and integrity has enabled it to stay relevant and win all election campaigns since 1959 (Lim and Daft, 2004: 50). By doing this way, Singapore business leaders has sustained, improved and enhanced corporate social responsibility in their businesses.

\section{The Value of Ethics}

Aleaxander Solzhenitsyn (1918-2008), a Russian novelist and historian, said, "Even the most rational approach to ethics is defenseless if there isn't the will to do what is right." This is very similar to what Mencius had said, men are inherently good (Lin, 1994; Chan, 1973) and that man has the will and the conscience to do what is right. Individuals have ethical attributes that can be cultivated and extends outwards. Currently, to these researchers, there is a need for ethical renewal by applying an inside-out approach. Mother Earth is sick; there should be ethical concerns, not to say, the many environmental concerns, by all. China and India are growing but "the vast majority of Asia's poor are rural", "millions more are barely getting by (surviving)" (Wehrfritz; 2008; italics, mine), there are problems of income gaps and other issues. As earlier said, technologies are also changing and with it, various ethical issues. Take, for example, just recently, a ferocious tsunami spawned by one of the largest earthquakes ever recorded slammed Japan's eastern coast on Friday, 11 March 2011, killing hundreds of people as it swept away boats, cars and homes while widespread fires burned out of control. Following these events, a nuclear power plant at Fukushima, after stricken and damaged by the tsunami, produced an accumulation of hydrogen near the nuclear reactors and caused large explosions that heavily damaged the outer buildings housing them. The disasters also knocked out the reactor 
cooling systems, triggering more explosions and fires and releasing radiation. The crippled plant suffered an extensive radioactive materials leakage polluting the air, water (marine life) and land (vegetation) surrounding the area (Singapore Straits Times, 2011). The emitted radioactive materials have also contaminated the fishing village, farm produce and drinking water. The contaminated water raised concerns about the safety of seafood in the country that gave the world sushi, prompting the government to set limits for the first time on the amount of radiation permitted in fish (Singapore Straits Times, 2011a). Residents living nearby the nuclear plant have to be evacuated to other safer places away from the radiation hazards. And several weeks had passed since the Japanese plant operator, together with the help of the world nuclear experts, were trying to contain the damage i.e. to prevent the radioactive materials leakage from spreading further (Singapore Straits Times, 2011b).

Although natural disasters such as earthquake and tsunami cannot be foreseen and be prevented, however, the authors felt that if the Japanese can continue to learn from their past history (experiences), the disaster may have been avoided or minimize. In Confucianism, one should learn not only from the past, but also, from mistakes. Confucius said, "I was not born with knowledge, but, being fond of ancient culture, I was eager to seek it through diligence." (Analects of Confucius, VII: 20). What are then the learning points from this recent Japan's disaster?

On the one hand, using all these experiences and information past down by their ancestors, Japan may have effectively utilize all these information and craft a better policy to protect the homes and livelihood of its people against natural disasters. Through history, one may map out the frequent tsunamis occurrence coastline, and this would provide a basis for further resettlement in order to protect the future descendants. On the other hand, Japan nuclear crises might have been avoided if a careful and intensive feasibility study has been carried out beforehand, especially on the decision making of building a nuclear plant near to the epi-centre of the volcanic area and that this feasibility study should also include proactive crises management if unforeseen accidents do happen. Referring to this event, one can see that the Japanese response to the nuclear crises was too slow and was based on trial and error basis; more proactive crisis management could be applied.

On 7 July 2011, News International announced that the News of the World would be permanently closed that week, the last issue being produced on Sunday 10 July 2011. The 168-year-old newspaper folded over the weekend in the wake of accusations that its reporters illegally eavesdropped on the phone messages of murder and terrorism victims, politicians and celebrities. Police in United Kingdom identified almost 4,000 potential targets of phone hacking. There were also allegations that reporters may have bribed law enforcement officers. (CNN News, 2011). The closure was in response to the developing phone hacking scandal, after a private investigator allegedly hacked into the phone of murdered British teenager Milly Dowler possibly interfering with the police investigation and causing distress to the girl's parents. The murdered schoolgirl's mobile phone was allegedly hacked by the News of the World during the search for her in Surrey in 2002. The allegations led to a public backlash and the loss of advertising revenue, as a number of companies advertising with the paper pulled out pending an investigation. The scandal deepened when the paper was alleged to have hacked into the phones of families of soldiers killed in action. As a 
result of the scandal, James Murdoch, Chairman and Chief Executive of News Corporation, Europe and Asia, announced on 7 July 2011 that the 10 July 2011 edition of the paper would be the last. On 8 July 2011 former editor Andy Coulson was arrested by police investigating phone hacking and corruption allegations. On the same day former News of the World royal editor Clive Goodman, jailed for phone hacking in 2007, was also arrested over similar corruption claims. This was followed by the resignation of Rebekah Brooks, chief executive of Rupert Murdoch's News International. Brooks was the paper's editor between 2000 and 2003, during which time Milly Dowler's phone was tampered with. Prime Minister David Cameron said her resignation was "the right decision", his official spokesman said.

This phone hacking scandal demonstrated the value of ethics is indeed important in our daily business. Just because of this ethical reason, Rupert Murdoch, the chairman and CEO of News Corporation, met the family of Milly Dowler and gave a full and sincere apology. Dowler's solicitor replied, "Your papers should lead the way in setting the standard of honesty and decency in the field and not what had gone on before. At the end of the day actions speak louder than words." (BBC News, 2011).

Another example of an organisation that had breached ethical conduct is WikiLeaks. WikiLeaks is an international non-profit organization that publishes submissions of private, secret, and classified media from anonymous news sources, news leaks, and whistleblowers. Its website, launched in 2006 under The Sunshine Press organization, claimed a database of more than 1.2 million documents within a year of its launch. WikiLeaks describes its founders as a mix of Chinese dissidents, journalists, mathematicians, and start-up company technologists from the United States, Taiwan, Europe, Australia, and South Africa. Julian Assange, an Australian Internet activist, is generally described as its director. The site was originally launched as a user-editable wiki (hence its name), but has progressively moved towards a more traditional publication model and no longer accepts either user comments or edits.

In April 2010, WikiLeaks published gunsight footage from the12 July 2007 Baghdad airstrike in which Iraqi journalists were among those killed by an Apache helicopter, as the Collateral Murder video. In July of the same year, WikiLeaks released Afghan War Diary, a compilation of more than 76,900 documents about the war in Afghanistan not previously available to the public. In October 2010, the group released a package of almost 400,000 documents called the Irag War Logs in coordination with major commercial media organizations. This allowed every death in Iraq, and across the border in Iran, to be mapped. In November 2010, WikiLeaks began releasing U.S. State department diplomatic cables. In April 2011, WikiLeaks began publishing 779 secret files relating to prisoners detained in the Guantannamo Bay detention camp. In 13 July 2011, Julian Assange, the 40-year-old computer expert was wanted for questioning on three allegations of sexual assault and one of rape, said to have taken place in Stockholm in August last year. The claims were made by two female Wikileaks volunteers. The High Court has deferred a decision on the appeal of Wikileaks founder Julian Assange against his extradition to Sweden to face sex assault charges (BBC News, 2011a). This example again shows that the importance and value of ethics. Because the wrong doings of a single person, the damage to the society at large and even to several other individuals has been done. Thus, the key point here is that one should be conscious of one's effect(s) or impact 
on others around us; indeed one needs to self -cultivate oneself to live up to the utmost virtues so that one becomes socially responsible, that is, to lead one's life well yet not causing any harm to others.

\section{The Value of Benevolence}

Elbert Hubbard (1856-1915), an American writer, publisher, artist, and philosopher said, "Down in their hearts, wise men know this truth: the only way to help yourself is to help others." And noticeably, love all and serve all is the Confucian message and when applied to the stakeholder theory, it becomes wholesome and without discrimination. Interestingly, Martin Luther King (1929-1968) also said, "Discrimination is a hellhound that gnaws at Negroes in every waking moment of their lives to remind them that the lie of their inferiority is accepted as truth in the society dominating them." Discrimination at workplace is a haunting reality of the corporate world even in this millennium. Bias, prejudice and differentiation treatment rather than actual job-related basis constitute discrimination.

However, Confucianism indeed puts the accent on humanism. Love for mankind. And may we add, love for nature too. According to Confucius, "no man is a machine. He should not behave heartlessly like one, or as if others were machines" (Chew, 2000: 5). "A gentleman is (also) conscious only in the knowledge of others' comfort; the mean is conscious only of his own comfort" (Chew, 2000: 2, italics mine). To be ethical on doing things, one has to consider the impact of the action onto the environment and the public at large.

As a teacher (business owners), Confucius further held that to bring forth good results, he must love his pupils (employees) (Yang, 1993; italics mine). He needs to know them well, understand their psychological particularities, give thought to ways and means of making easy their access to knowledge and, to that end, develop an effective methodology. Having said that, Confucius is also very insightful on assessing his disciples or dealing with people, he did judge a person not by one's word but by one's action. Take, for example, Zăi Yú, his disciple, always slept in the daytime. Confucius said resentfully, "One cannot expect to carve on a piece of rotten wood, nor can one expect to whitewash a filthy wall. As for Zăi Yú, what is the point of scolding him?" Confucius added, "I used to trust what people said, now I want to see what they do before I trust them. It is from Zăi Yú that I have learnt to change my attitude in dealing with people" (Analects of Confucius, V: 10).

The trademark of a teacher's virtue, in Confucius' eyes, was loving commitment through his lessons to his pupils' development. The teacher needs to look into the moral development of his pupils too, and that is an attractive way or value that a teacher may want to hold. In this respect, Confucius always cared and showed concern about his students especially when he was away from them. When he was in the State of Chén Confucius missed his disciples at home. He said again and again to those who accompanied him, "Let's go home! Let's go home! My students at home all have great ambitions and have the qualities of literary men, but they do not know how to regulate themselves" (Analects of Confucius, V: 22).

Confucius said, "One should choose to dwell in such a place where there are 
benevolent people who practice loving-kindness. Otherwise, how can one be said to be wise?" (Analects of Confucius, IV: I). Furthermore, the Master remarked, "Illcultivated men can neither be content in poverty nor happy in wealth. The wellcultivated man is always content in benevolence, and the wise man knows how to use benevolence" (Analects of Confucius, IV: II). To these researchers, a very good example of one who practices loving-kindness, as well as being influential and leading the Confucian way is that of the late Matsushita Konosuke (1894 - 1989), the founder of Japan's Matsushita Electric (Low, 2008). The business owner/ marketer should be people-centered. Putting "people before products" (PHP, 1994: 54), the business owner should also be responsible to his employees as well as customers, serving their needs. The late Matsushita Konosuke believed in respecting and developing people and consulting them on doing things. He said, "Consulting is better than ordering." He was known for broaching the topic as if seeking advice or offering a suggestion and he would never order his employees to do what he wanted them to do. In other words instead of simply saying, "Would you do such and such?" he would say something like, "I've been thinking we could do such-and-such this way; what do you think?" or "Would you undertake this job?" Thus, he made his employees comfortable and felt ease in presenting their own opinions and suggestions on the matter (PHP, 1994: 58 - 59).

Nowadays, there are many western examples of leading ethically and the Confucian way of giving back and contributing to the society and these can be seen as practiced by two American billionaires. One of such people includes Kenneth Fisher, an American businessman, founder and chief executive of money management firm, Fisher Investments. To him, loving is best shown by adopting the best way, and that is, giving back to the community by creating jobs for the people. Besides, he has willed 80 percent of his estate to John Hopkins for medical research rather than set up a trust (Tan, 2007; Low, 2008).

The other person is Warren Buffet, an American Investment Guru, who has donated $\$ 1.93$ billion to five charitable foundations in July 2010, the third-highest amount since the investor began donating 99 percent of his wealth in 2006. Buffett's donations totaled $\$ 1.93$ billion in 2006, \$2.13 billion 2007, \$2.17 billion in 2008 and $\$ 1.51$ billion in 2009 , according to regulatory filings and Berkshire's closing stock prices on the dates the donations were made. The size of the 2010 donation is just above the 2006 donation on that basis. Buffett urged American billionaires to pledge at least half their wealth to charity (International Business Times, 2010).

\section{The Value of Continuous Learning}

The benefit of continuous learning is that one can proactively investigates new perspectives, attitudes, and behaviors, and takes steps to evaluate and improve one's performance. Very truly, learning prevents one from being narrow-minded. For Confucius, it is important for individuals to learn. The Confucians see it as bad to eat one's fill all day long and do nothing to nourish one's mind. Confucius said, "A gentleman seeks neither a full belly nor a comfortable home. Instead, he is quick in action yet cautious in speech. He learns from virtuous and accomplished men in order to correct his mistakes. Such can be called a man with eagerness to study" (Analects of Confucius, I :14) As what Confucius has very well defined the phrase "a man with 
eagerness to study" as somebody who is not merely study by oneself but who is also willing to learn from good and experience men (teachers) in order to correct one's mistakes.

In terms of the values of learning and education as well as integrity, Low (2006b, citing Sie, 1997 and Cham, 1998) has highlighted these: Wu, a Chinese scholar mentioned that learning, or the Confucian concept of keji (one must learn and be ready to move), was important to Singapore and its future. Keji was also reflected in the way the Government made its education, IT and technology plans about 30 years ahead, and Singaporeans must learn to move ahead in today's world. In a true Confucian fashion, the Singapore Government has invested much to better the Singapore workers' educational status. University education is also given much emphasis; the government is seeking to make local universities world-class and best in the region; and with Singapore's ambition to be the knowledge centre of the region, it is only natural to emphasise research and development. To Confucius, "the gentleman broadens himself by scholarship or learning, and then regulates himself by li (proper conduct or moral discipline)". The Confucian leader, even in the modern day, stresses on learning, education and high integrity. Its investments on schools and education are high (Low, 2009; 2002). Having the Confucian Heritage practical thriver culture (Low, 2009; 2002; 2011), the Singapore Government relies on the Mandarinate or scholars to administer the Citystate. Although appearing elitist, the efficient and honest civil service promptly attended to the needs of its citizens, and it is said that for Singapore everything was on the table with clear rules (Thurow, 1996 and Schein, 1996, cited in Low, 2009; 2002). Low (2008) has indicated that high integrity is up-kept with the Corrupt Practices Investigations Bureau (CPIB) under the charge of the Prime Minister's Office. Indeed, as Confucius highlighted, "We are saying (emphasizing) all the time: Li! Li!'” (Lin, 1994, 200, italics mine).

The Confucian practitioner sets the heart right (ethical goodness, awareness and reasoning); and does personal cultivation (ethical action and leadership). Learning and improving never stop. To the Confucian gentleperson, to be capable, one must study; to be intellectual, one must learn from others (Zhou, 2005: 36), profiting by good examples and avoiding bad examples. (Chew, 2000: 13). To these researchers, the Confucian gentleman benchmarks, learns and improves. It's also Kaizen (continuous improvement) in the ethical sense; continuous improvement indeed builds and grows his or her moral fiber. And when thus effected in running a country, it means good governance is carried out.

\section{The Value of Teamwork \& Team Spirit}

In Hong Kong, during the dragon boat festival (Duanwu festival), one can see drums pounding and oars ripping through the water. A well-trained crew works at feverish pitch. The goal is to bring the dragon boat across the finishing line first. Dragon Boat Racing has its roots in Chinese mythology, but it's a fast-paced, exciting international sport. Each race lasts a few minutes, so split seconds matter and teamwork is everything. The achievers will practise rowing in a team, and then take off as arms and oars vanish in a blur of speed. The speed, the timing, the power of teamwork and team spirit are at its best. In this respect, Confucius also stressed the importance of talents and teamwork to get the job done effectively. The Master said, "When it 
comes to formulating a document of law or decree in the State of Zhèng, usually it is $P i$ Chén that would work out the draft; Shi She that would put forward specific suggestions; $Z \check{\imath} Y \check{u}$ that would revise it; and finally, it is Ž̌ Chăn that would polish it. The documents worked out through the common efforts of the four wise senior officials seldom suffer flaws" (Analects of Confucius, XIIII: 8). In this respect, Confucius explained clearly how each person's potential and capability in team work can contribute to the spirit of a team leading to the success of a team. Therefore, team dynamics and harmonious relationships are important. If a team consists of players who are too opinionated in their views with no agreement reached in any decisionmaking, team members have to spend much energy in convincing each other and sometimes to no avail. In this respect, teamwork and harmonious relationships are both important factors in team success.

Confucian leaders value long-termism, and thus stress much on relationshipbuilding. The reason being that societies cannot survive if everyone does not cooperate and collaborate for the common good. Or to put it in the positive sense, everyone in the society chips in; builds relationships ; contributes, cooperates and collaborates for the greater goal of the common good; and the society progresses (Low and Ang, forthcoming).

In CSR, positive thinking and positive team spirit plays an important role in team development and collective motivation of the people. Furthermore, team work with personality tolerances would help and align the team members in experiencing an energy shift that would forever change team dynamics and providing a long lasting result. Figure-1 illustrates positive thinking is important for positive team spirit.

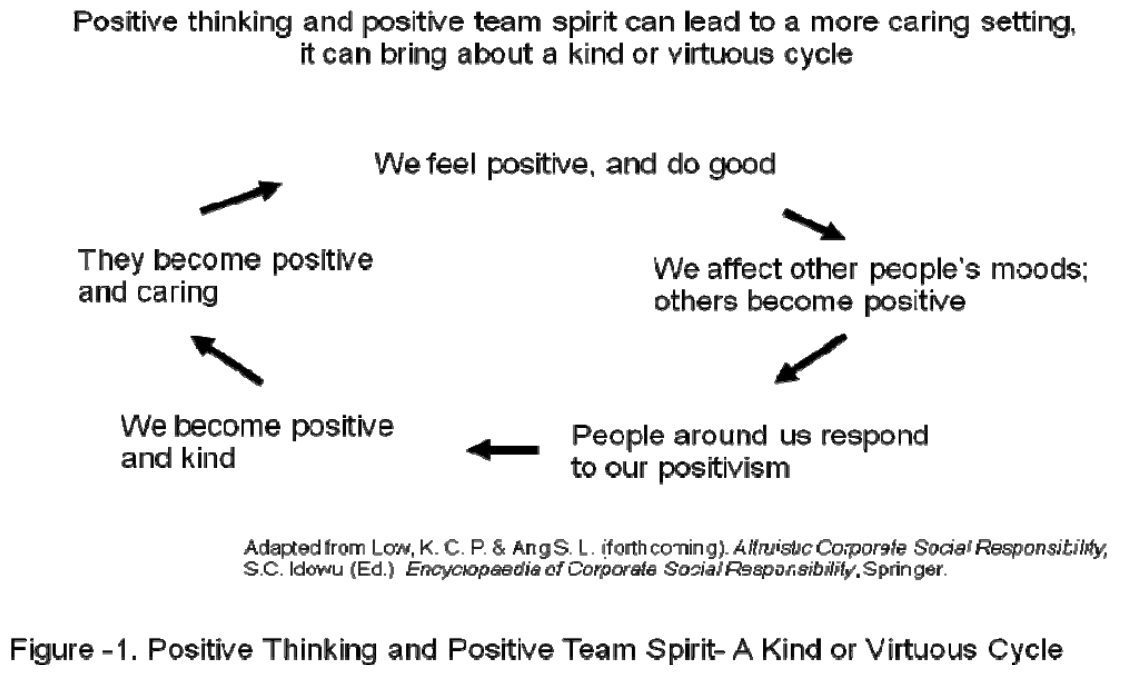

\section{The Value of Good Governance}

It is true that a well balanced, inclusive approach, according to certain standards and ideals, is imperative for the proper governance of an organization. Leaders and managers should closely monitor employees' decisions to ensure that they are made in the best interests of the owners and the people at large and that corruption is 
avoidable. Employees' compensations may be awarded directly tied to the firm's performance. The firm's financial reporting should also be accurate and transparent; it should give complete financial statements, those that are more understandable and more readily interpreted. Firms need to fulfill their responsibility to their creditors by providing good financial reporting. As in the Enron case by conspiring with the auditors and concealing some debts that the company had incurred, Enron was able to more easily borrow funds and ultimately, it went bankrupt because it could not cover the payments on all of its loans. Specifically, Enron did not disclose some of its debts and indeed, its creditors would have been concerned about extending more credits if they had fully understood how much debt Enron already had. In this respect, good governance run by a team of good and reliable people would help and improve the society in a socially responsible way.

\section{The Value of Talent}

Talent or human capital is the primary driver of any successful company, better talents will definitely differentiate higher performance companies from the rest; and talent management is critical when it comes to business excellence and success (Low, 2010d). In this respect, people should be valued and talents respected. Confucius cared most about people.

When the stables burned down, Confucius enquired if any person had been hurt but did not ask about the horses. He recognized the free will of every individual, believing that the commander of three armies could be removed, but the will of even a common person could not be taken away (Low, 2010). In this respect, the business also needs to attend to its employees and their needs, providing stable employment, security, fair pay, and safety as well as the fact that employees are treated properly by other employees. Here, satisfying employees, the key issues in modern businesses include diversity, equal opportunity and the prevention of sexual harassment (Madura, 2007).

With regard to the value of talent, Confucius said, "Some seedlings spring up but never blossom, others blossom but never bear fruit" (Analects of Confucius, IX:22). What Confucius has indicated here is that there are individuals who can be groomed to do specific tasks satisfactorily and there are some who can not. Therefore, in order to ensure good leadership succession plan for the future, leaders are committed to grow individuals. Confucius was also aware and positive of the fact that young people can be groomed to be future leaders and he remarked, "Young people have great potential for achievements. Who can say that they will not be our equals in the future? If someone has not distinguished himself by the age of forty or fifty, he will not amount to much" (Analects of Confucius, IX: 23).

When an organisation is run by team of good talents via prudent human resource development and management, it would help the business in finding opportunities and challenges proactively and in seeking businesses that are corporate socially responsible. 


\section{The Value of Peace and Unity}

Confucius lived in times when there was constant warfare between neighboring states and local warlords had little concern for the high moral principles. He taught the people on the value of family closeness and fatherly care and stressed the importance of peace and unity in social relationships. It is very true that when the families are unstable, and if there are break-ups and quarrels in the families, the whole country is not stable. If the families are at peace, the country is stable and at peace too. Businesses are also run along the family line, creating a congenial family or small group atmosphere.

Confucius stresses on the importance of the family; and in the family unit, the father is the key figure. He should be the role model, a good example to his children. For the son, it is the son's duty to obey without questioning and honor his father, even after death. When the father dies, obedience is given to the oldest brother. Confucius states in the Analects, "Meng I Tzu asked about the treatment of parents. The Master said, 'Never disobey! ...While they are alive, serve them according to ritual. When they die, bury them according to ritual and sacrifice to them according to ritual"' (Analects of Confucius II: 5).

Showing care and concern to his followers, the benevolent Confucian leader is like a father to his followers. Besides, the family spirit is often fostered, and to quote Confucius: A true gentleman is in harmony, and is friendly with others though he does not agree with them...(Chew, 2000: 17).

In the small business situation, the father leader/ small business-owner collaborates with his "family members" in a purposeful team fashion, "rubbing shoulders and doing something together also gives the opportunity to share. There is joint purpose, sharing the same dreams and bringing the relationship to a higher plane. There is also synergy" (Low, 2007; 2005; Low 2001: 101). Employees' successes are celebrated and with effective team leadership, teamwork is fostered and higher performance attained (Zimmerer \& Scarborough, 2006, cited in Low, 2007). At the core, it appears that this teamwork, or more appropriately, consensus-seeking culture may be related to loyalty, which is also considered to be a virtue by the Chinese (Bond, 1987, cited in Low, 2009b; 2002). Chinese are taught from a young age to be loyal to their family and kin. Hsu (1984) claims, loyalty to the family will continue to play a critical role among Chinese. Family is important in any culture, but it is extraordinarily so in Chinese culture. But more importantly, "relations among family members provide the human basis for the moral virtues of the Chinese" (Nakamura, 1978, cited in Low, $2009 b$; 2002). Hsu (1984) has identified some of the significant characteristics of the Chinese family that have a strong impact on Chinese organizations. The Chinese as a people are special in their relationships with others, and a strong emphasis on the importance of blood relations, parental authority, filial piety and loyalty exists. The late Kwek Hong Png, founder and chairman of the Hong Leong (Singapore) group of companies, for instance, pointed this out when he was expanding his business. Attentive to the old Chinese proverb that "when tackling a tiger, one needs the help of one's brothers, I (Kwek) invited my brothers to join my firm" (Kwek, 1987, cited in Low, 2009b; 2002). 


\section{The Value of Caring Towards All Others and Also For the Environment}

Caring for others is an important aspect of opening up oneself by engaging in relationships with other persons in the community at large. It would help an individual to improve one's relationship when one demonstrates interest, concern and attention; and it also helps one to become less self-absorbed and more empathic. Volunteering and helping with charity work is something many of us feel that we would like to do but cannot afford the time. Looking at ways to give something back to society and feel more invested in it is very satisfying and rewarding. There are many areas where charity and voluntary work are involved. Children, animals, environmental, search and rescue are some of the areas that rely on unpaid help to survive. Finding an area that is of particular interest can add an important dimension to one's life, introduce one to new skills and people and enhance one's quality of life. By finding positive ways to care for others one adds value to one's life, feel more engaged with others and generate a more constructive, healthy, sharing way of living with others. One can improve the quality of life for everyone.

Here, the Indian nationalist Mohandas Gandhi (1869-1948) once said, "The earth, the air, the land and the water are not an inheritance from our fore fathers but on loan from our children. So we have to handover to them at least as they were handed over to us." In this regard, the firm needs to ensure its responsibility to the community. It should be socially responsible. It needs to take care of and protect the environment. Firms need to prevent air, water and land pollution. Automobile and steel firms have reduced air pollution by changing their production processes so that less carbon dioxide escapes into the air (Madura, 2007). China, for example, has admitted that it has failed badly; the country has not made much headway in improving the environment, says its Government Report (Tschang, 2007). In this aspect, present day China needs to apply the Confucian values in conjunction with the stakeholder's theory - particularly in terms of the firm's responsibility to the environment - to make Mother Earth a healthier and a more pleasant place for all to live. The Chinese needs to realize that in traditional Chinese/Confucian mind, men exist in harmony with nature (One with Nature), and unlike in the Western mind, traditionally, nature is to be conquered; there is a dominance orientation (Adler, 2008).

\section{The Value of Contribution to The Society}

One of the key challenges faced by the successful business leaders is that of 'giving back' or returning to the community some charitable services or aids. In this manner, (s)he attains the goal of greater common good by subscribing to and upholding Confucian values and the stakeholder's theory. Furthermore, to be a responsible individual, one should not condone any activity which is not right or against human rights. Therefore, child prostitution, like child slavery, should not be simply accepted or tolerated by the business leaders. It is a gross abuse of the human rights of those who are least able to do anything. Whoever one is and whatever one does, one should and must do something about it. Just imagine if it happened to one when one were young, or to one's own child. Individuals and companies alike need to raise public awareness such as sponsoring children education in developing countries and/or sponsoring some awareness events including posting Internet articles and printing simple leaflets [which could include facts and figures to end sex trade/trafficking, 
prostitution, pornography and child sex tourism]. Street children (they are human beings who need the basic human rights too), particularly in developing countries, can also be attended to. Companies can also help to improve their welfare, and thus fulfilling their CSR while contributing to the society's well-being. The families of street-children are often too poor to feed an extra mouth; and among other things, companies can help by giving meals, books/ educational resources and old toys and improve their welfare. Besides street-children, companies can also help prisoners by sending them books so that they can educate themselves to a get a high-school diploma or a college degree (Low and Ang, forthcoming a). In sum, the core values of a Confucian leader can be summarized as Figure- 2 .

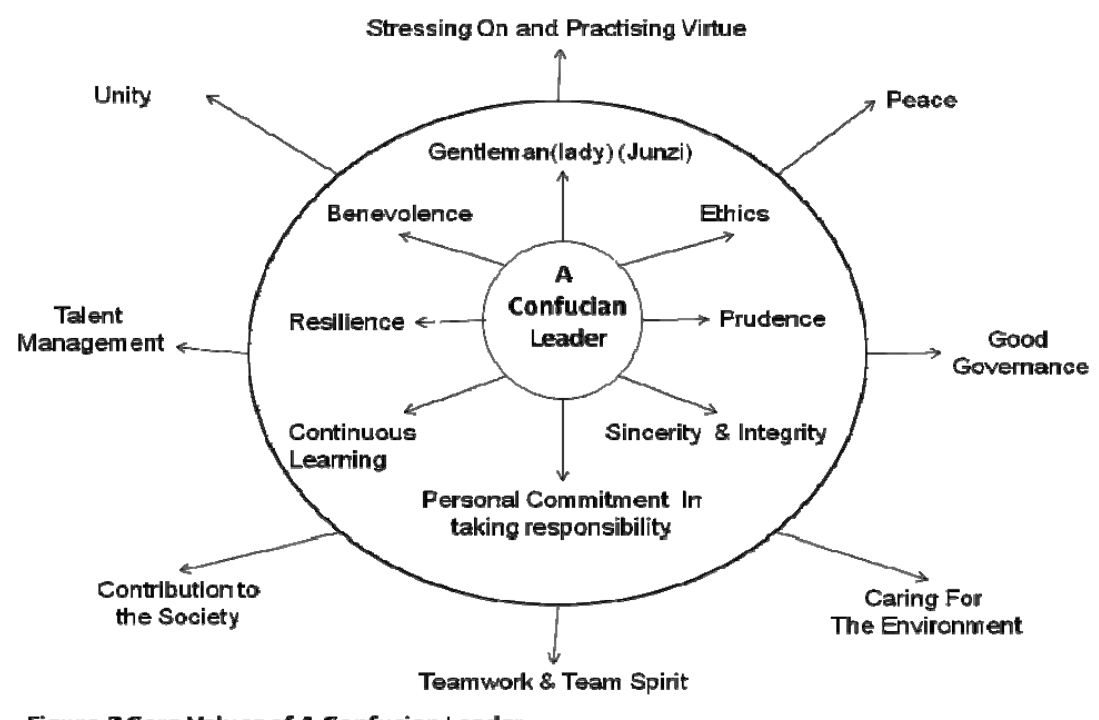

Figure-2 Core Values of A Confucian Leader

\section{Confucian Leadership and Corporate Social Responsibility}

Upholding Confucian values enable leaders to self-cultivate themselves via continuous learning towards positive business dealings and harmonious relationships; and these bring many advantages, usefulness and good practices including good business management in supporting Corporate Social Responsibility. (This is well illustrated and summarised in Figure-3). 


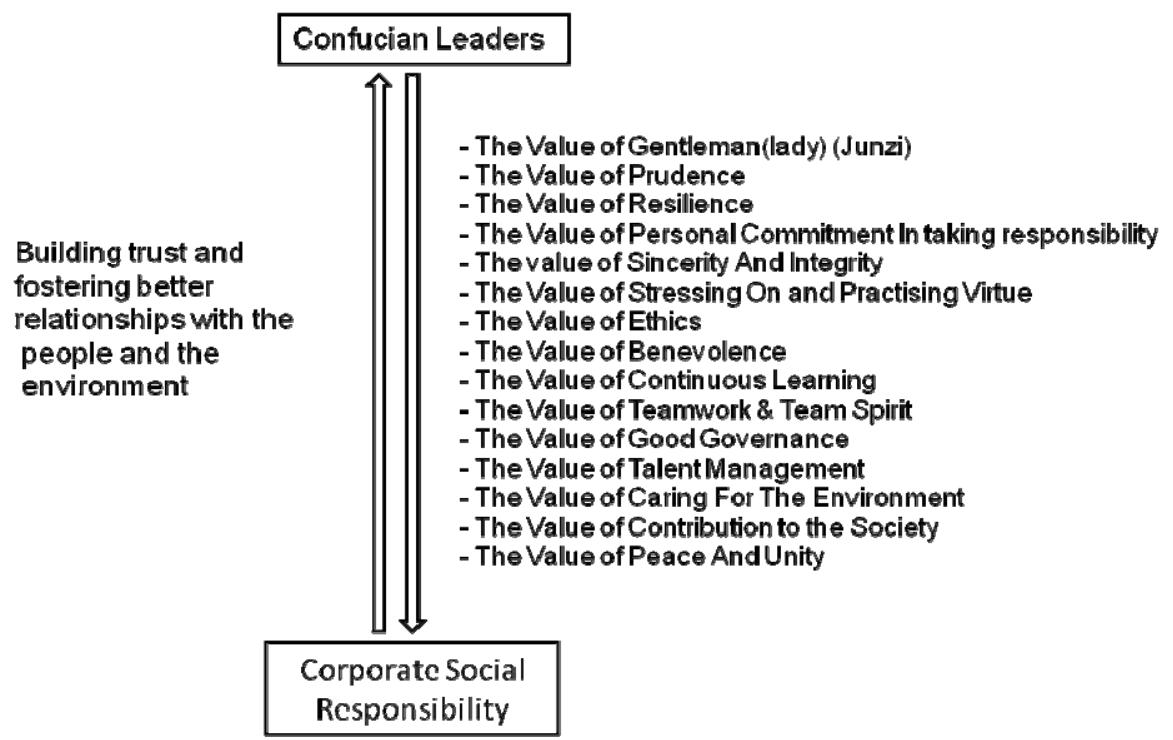

Adapted from Low KCP and Ang SL (2011). 'Confucian Ethics and The Stakeholder Theory in Business', Journal of Management. Mar-May 2011 issue, iManager Publication.

Figure-3. Confuclan Leadership And Corporate Social responsibility

\section{Concluding Remarks}

Confucian leadership is significantly aligned and in support of the concept of corporate social responsibility. The concept of Confucian leadership is, first of all, started with helping an individual to develop and self-cultivate oneself through relationship and continuous learning to be a better person (gentleman/lady) so that (s)he can later lead more people to help themselves and contribute to the society. When good people leads, motivates and influences other people to be ethical and to do good for the society, more people would become ethical and do good for the society. This coincides very well with the concept of corporate social responsibility in which business leaders are committed to contribute to sustainable economic development, working with employees, their families, the local community and society at large to improve their quality of life (WBCSD, 2002). All in all, the Confucian business leader grows or 'perfects' one's virtue. Being just and ethical to humanity, the Confucian business leader would build one's credibility, and has the right status so that what one says is justifiable is in alignment with CSR. When Confucian business leaders' words are justifiable, then what one does can be effective and successful - one is respected and emulated by his or her followers (employees, customers, suppliers, investors and community). 


\section{References}

Adler, N. J. and Gundersen, A. (2008), International dimensions of organizational behavior, Thomson South-Western, USA.

BBC News (2011), 'Dowler family statement after meeting Rupert Murdoch' dated 15 July 2011, http://www.bbc.co.uk/news/uk-14168283

BBC News (2011a), 'Wikileaks' Julian Assange extradition decision deferred' dated 13 July 2011, http://www.bbc.co.uk/news/uk-14139329

BBL, (2011), Biographies of Business Leaders@Woopido.com retrieved 22 July 2011. http://www.woopidoo.com/biography/rupert-murdoch.htm.

Chew K. H., P. (2000), A Gentleman's Code, Graham Brash (Pte) Ltd, Singapore.

Chin, A. (2008), 'Confucius: A life of thought and politics', St.Edmundbury press Ltd, Great Britain.

CNN News (2010), 'Murdoch begins series of apologies in phone-hacking scandal' dated 16 july 2011. http://edition.cnn.com/2011/WORLD/europe/07/15/uk.phonehacking.scandal/index.h tml?hpt $=$ hp_bn1

Fukukawa, K. and Teramoto, Y. (2009), 'Understanding Japanese CSR: The Reflections of Managers in the Field of Global Operations' Journal of Business Ethics (2009) 85:133-146.@ Springer.

Hsu, Paul, S. C. (1984), Unpublished Paper, The influence of structure and values on business organisations in Oriental cultures: A comparison of China and Japan, School of Management, National University of Singapore, Singapore - June.

Isaak, R. (1997). 'Making 'economic miracles': Explaining extraordinary national economic achievement', American Economist, Vol. 41, Issue 1, Spring 1997, pp. 59-69.

Ivancevich, Konopake \& Matteson (2008). Organisational Behaviour and Management, Eighth Edition, McGraw-Hill International Edition. pp. 413.

Lim, G. S. and Daft, R. (2004), The leadership experience in Asia, Thomson Learning, Singapore.

Lin Y. (ed.) (1994). The Wisdom of Confucius, The Modern Library, New York.

Low K. C .P. (2011) 'Types of Singapore Corporate Culture', Business Journal for Entrepreneurs, Volume 2011 Issue 2, p. 11 - 49.

Low, K. C. P. (2010). 'Zen and Leadership - Growing One's Leadership Excellence', Insights to A Changing World, Volume 2010 Issue 1, pp.1 - 10.

Low, K. C. P. (2010a). 'Proactive Leading, the Buddhist Way', Country: Thailand Business Environment/ Living, GLOBALTRADE.net 
Low, K. C. P. (2010b). 'Leading the Mahatma Gandhi Way', Leadership \& Organizational Management Journal, Volume 2010 Issue 2, pp. 110 - 117.

Low, K. C. P. (2010c) 'Values Make A Leader, the Confucian Perspective', Insights to A Changing World, Volume 2010 Issue 2, p. 13 - 28.

Low, K. C. P. (2010d) 'Talent Management, the Confucian Way', Leadership \& Organizational Management Journal, Volume 2010 Issue 3, p. 28 - 37.

Low, K. C. P. (2009). 'How to lead in today's context? What leadership skills set do we need?' Leadership \& organizational management Journal, Volume 2009 Issue 1 pp. $48-56$.

Low, K. C. P. (2009a). 'Leading globally - What makes a successful global Leader in today's turbulent times', e-Leader Estonia Conference, CASA: Chinese American Scholars Association 8 - 10 June 2009, Tallinn, Estonia.

Low, K. C. P. (2009b). Corporate Culture and Values: Perception of Corporate Leaders of Co-operatives in Singapore, VDM-Verlag, Germany.

Low, K. C. P. (2008). 'Confucian Ethics \& Social Responsibility - The Golden Rule \& Responsibility to the Stakeholders' Ethics \& Critical Thinking Journal, Volume 2008 No. 4, pp. 46-54.

Low, K. C. P. (2006). 'Motivation, the Chinese leadership way in Singapore's small and medium companies'. The Icfaian Journal of organizational behavior, Vol. V No.1, January, 2006, The Institute of Chartered Financial Analyst India: ICFAI University Press, pp. 80 - 90.

Low, K. C. P. (2006a). 'Father Leadership - The Singapore Case Study', Management Decision, Emerald Insight (www.emeraldinsight.com/0262-1711.htm), Vol. 44 Issue 2, March 2006, pp. 89 - 104.

Low, K. C. P. (2006b). 'Crisis management - Can core values be considered as a built-in safety net? The Singapore case', Insights to A Changing World, http://franklinpublishing.net/insightstoachangingworld.html, Franklin Publishing House, Volume 2006, Issue 3, pp. 133 - 150.

Low, K. C. P. (2005). 'Towards a Framework \& Typologies of Singapore Corporate Cultures' Management Development Journal of Singapore, Vol. 13, No. 1, May 2005 , p. $46-75$.

Low, K. C. P. (2005a). 'Values that Contribute to Companies' Success - Perceptions of Singapore Corporate Leaders', Effective Executive, April 2005, The Institute of Chartered Financial Analyst India: ICFAI University Press (http://www.icfaipress.org/effective.asp), p. 45 - 55.

Low, K. C. P. (2002). Corporate Culture and Values: Perception of Corporate Leaders of Co-operatives in Singapore, Ph.D. Thesis, the University of South Australia, Adelaide.

Low, K. C. P. (2001). The power of relationships, BusinesscrAFT ${ }^{\mathrm{TM}}$ Consultancy, Singapore. 
Low, K. C. P. and Ang S. L. (2011). 'Confucian Ethics and The Stakeholder Theory in Business', Journal of Management, Mar-May 2011 issue, iManager Publication.

Low, K. C. P. and Ang S. L. (forthcoming). Christianity and Corporate Social Responsibility, S.O. Idowu (Ed.), Encyclopaedia of Corporate Social Responsibility, Springer.

Low, K. C. P. and Ang S. L. (forthcoming a). Blue Ocean Theory and Corporate Social Responsibility, S.O. Idowu (Ed.), Encyclopaedia of Corporate Social Responsibility, Springer.

Madura, J. (2007) (4 $4^{\text {th }}$ edition). Introduction to business, Thomson South-Western, Canada.

Pay, R. (2000). Confucius. Web-site: http://www.humanistictexts.org/confucius.htm. Accessed on 27 June 2008

PHP, (1994). Matsushita Konosuke (1894 - 1989): His life \& his legacy, PHP Institute, Inc., Japan.

PHP, (1991). Velvet glove, iron fist, PHP Institute, Inc., Japan.

Singapore Straits Times (2011). 'Tepco president under fire from Japan lawmakers', dated 19 April 2011.

Story, C. (2007). Asian Studies/ Confucianism, Web-site: http://www.castilleja.org/faculty/christy_story/C\&C/Buddhism/confucius.htm. Accessed on 5 June 2007.

Singapore Straits Times (2011a). 'Tepco moves to prevent new explosion at plant' dated 6 April 2011, (http://www.straitstimes.com/BreakingNews/Asia/Story/STIStory_653569.html)

Singapore Straits Times (2011b). 'Sea radiation is another blow to Japan's fishermen' dated 6 April 2011, Website: http://www.straitstimes.com/BreakingNews/Asia/Story/STIStory_653501.html

Tan, L. (2007). 'Best way to give back? Create jobs,' says billionaire', The Sunday Times, 30 September 2007, pp. 24.

Thinkexist.com (2011), Bill Gates Quotes retrieved on 22 July 2011.

http://thinkexist.com/quotation/great_organizations_demand_a_high_level_of/147242.html

Tschang C. C. (2007). 'Ecology: China Admits It Has Failed Badly', The Straits Times, 29 January 2007, pp. 2

Transparency International. (2010). 'The 2010 Corruption Perception Index 2010 Results' Retrieved on 7 April 2011.20 Website: http://www.transparency.org/policy_research/surveys_indices/cpi/2010/results.

Wang, G. (2004). 'Confucianism', F-J Richter \& P. C.M. Mar (eds.) (2004) Asia's New Crisis: Renewal through total ethical management, John Wiley \& Sons (Asia), Singapore, p. 51 - 62. 
WBCSD (2000). Corporate social responsibility: Meeting the expectations. The World Business Council for Sustainable Development (WBCSD), Available at: http://www.wbcsd.org/DocRoot/RGk80O49q8ErwmWXIwtF/CSRmeeting.pdf

WBCSD (2002). Corporate social responsibility: The WBCSD's Journey, Available at: http://www.wbcsd.org/DocRoot/I0NYLirijYoHBDflunP5/csr2002.pdf

Wehrfritz, G. (2008). 'The price of survival', Newsweek, 8 September, 2008, pp. 39

World Bank Institute (2010). 'The Worldwide Governance Indicators (WGI) project' retrieved on 8 April 2011, Website: http://info.worldbank.org/governance/wgi/index.asp

Yang H. (1993). 'Confucius (Kung Tzu) 551 - 479 BC', Prospects: the Quarterly review of comparative education, UNESCO: International Bureau of Education Vol. XXIII No. $1 / 2 \quad$ 1993, $\quad$ p. $211 \quad$ - $219 . \quad$ Web-site: http://www.ibe.unesco.org/publications/ThinkersPdf/confucie.PDF. Accessed on 29 June 2008.

Yu, D. (2009). 'Confucius from the heart: Ancient wisdom for today's world', Macmillan, Great Britain.

Zhou, K. (2005). A basic Confucius (1st edition), Long River Press, China. 